\title{
Study on the Application of Cross-Cultural Research on English Teaching
}

\author{
Shanshan Lang ${ }^{1, a}$ \\ ${ }^{1}$ College of Humanities \& Sciences of Northeast Normal University, Changchun, Jilin, 130117 \\ ${ }^{a}$ email
}

Keywords: Cross-Cultural Studies, English Teaching, Application

\begin{abstract}
The main difference with the rest of English subjects in English disciplines that relate to a third party culture, with the accelerated process of economic and cultural globalization, the importance of this door universal language of English is self-evident, this article focuses on College English teaching cross-cultural research and application problems, and these issues targeted measures, cross-cultural studies in English education to provide effective guidance.
\end{abstract}

\section{Introduction}

Cross-cultural factors application is English teaching is a very important part of English is a communicative language, the main purpose of learning English should be fluent in use in everyday life, so in English teaching, teachers should not only taught correct English grammar knowledge, but in conjunction with the historical background and cultural traditions of English as a third language will be taught cultural knowledge. As English is the discipline involves different cultural background, and in the communication process, a lot of misunderstanding on the exchange are from the English use of national cultures do not understand, so students in the learning process should take the initiative to understand the target country cultural knowledge of English in order to have a thorough understanding of, truly improve their language proficiency.

\section{Cross-cultural Research Application on College English Teaching}

English teaching not only teach vocabulary, grammar, listening, reading, writing and other aspects of knowledge, and because of the special nature of the English discipline, which involves the use of English cultural background of the country, which is not an accurate grasp of the vocabulary and grammar is really to learn English, but should learn more about the application background syntax, such as textbooks in English, every word will correspond to a few Chinese meaning, but have a different interpretation of the same word in different contexts, which requires students according to different Context accurate translation.

With the implementation of the new school curriculum, although many college English teachers have begun to pay attention to cross-cultural research in English teaching, but they are due to some inherent limitations, lack of knowledge of cross-cultural understanding of the system, at the same time, most of the English teachers for our local culture is also a lack of deep understanding of the system so they are difficult to instruct students in English between native culture and cultural well balanced, comprehensive background knowledge can not compare in Western culture, leading the student can not correctly understand the culture background, so in order to improve the efficiency of English teaching, English teachers need the knowledge of Western culture have a deep understanding, open and inclusive attitude to cross-cultural research in English teaching.

Although China's university education level has been greatly improved, more and more universities and educational level of international standards, but in some teaching methods still exist some backward factors, especially in English teaching. University is mainly used in the target culture system in college English teaching, English teachers in the teaching process, mainly the large amount of time is applied to the memory and the study of grammar vocabulary, although some university foreign language teachers in the classroom will lead students play games, but most of the games and the line was around the vocabulary and grammar, very little penetration teach English 
cultural background knowledge.

Meanwhile in English teaching, most teachers did not pay attention to the dominant position of students, and did not use a variety of teaching methods, influenced by the reality of the situation, it is difficult to be individualized English teaching, English teaching is not only requires students to master this basics of discipline is more important is to make students able to skillfully use in working life this language, so university teachers must broaden educational methods, and actively play the dominant position of students, cultural knowledge penetrate into the teaching of English, try to improve Teaching Quality.

English Teaching Material Usually change is very slow, very difficult to keep up with the trend of world culture, and less emphasis on teaching English to teach cultural knowledge, and teachers lack of initiative and cultural knowledge into the classroom enthusiasm, but most teaching English expertise, while some statements did not go in-depth analysis of the subsequent cultural knowledge, and English textbooks covered for Western cultural content rarely, difficult for students to learn from textbooks real cultural background, the current English lectures mainly in response to the test as the goal, in this context also caused a university English teacher does not attach importance to cultural knowledge integration in learning, leading students to most of the energy used in the vocabulary and grammar of learning, rather than to study the statement cultural knowledge behind, so this is obviously not conducive to expanding the horizons of college students, not conducive to improving their English communication level.

\section{Measures to Improve Attention of Cross-cultural Study on English Teaching}

To truly grasp the essence of a subject, in this cultural context must discipline has a profound understanding of the rapid development of China's economy, the importance of English discipline is also more prominent, college English teachers to teach English expertise at the same time, we should pay attention to teach cultural knowledge, which requires English teachers not only to the cultural background of English country have a better understanding, while in-depth study of the national culture, so as to expand the impact of different cultural knowledge between teaching in .

Most importantly, an English teacher from the heart noted the importance of cross-cultural studies of English teaching, teaching a discipline involves not only the basics, but also requires a comprehensive teachers' grasp of the cultural background, so English teachers to improve own cultural enrichment, only teachers themselves have a rich cultural heritage, in the process of teaching high school students to the discipline of English have a more in-depth study.

Currently English teaching, English teachers rarely take the initiative to discover the traditional mode of teaching problems and therefore rarely innovative teaching methods, resulting in the quality of teaching in English is not too high for the English teaching in these issues, English teachers need to play in teaching initiative and guide the students with questions to learn and train students to develop the habit of initiative to solve the problem.

In imparting knowledge of English, teachers need to have some purpose of cultural knowledge of English interspersed into the English teaching to allow students to experience English culture and feelings, but also pay attention to national and traditional culture of teaching, so that students balance between two cultures knowledge, in imparting cultural knowledge, and allows students more comprehensive grasp of English professional knowledge, enhance student interest in learning, improve cross-cultural awareness.

Students learn the subject, even the best, if not the student's own teacher taught awareness of active learning, then it is difficult to achieve a good teaching effect.

On the one hand, teachers in the teaching process to the cultural knowledge into teaching, by comparison of Western culture for students to deeper understanding of knowledge of English, can be used in teaching comparative law, grammar-translation method or the like as much as possible reflect the different cultural differences, and by some teachers and students, interaction between students and students to reflect the application of cross-cultural knowledge.

On the other hand, the student body as a learning process, learning book knowledge, to dabble in a variety of extracurricular books, some in English and can communicate through practice English 
horn, etc., in person to experience different cultures, and such cross-cultural knowledge to learn English while some of the difficulties encountered in the study for, students should create awareness initiative to solve the problem, so that the difficulties.

\section{The Significance of Cross-cultural Study on English Education}

English common discipline both remaining subjects, also has its own characteristics, as a teaching basic subjects, students acquire specialized knowledge in this discipline, such as memorizing grammar and vocabulary, and English as a door universal language of communication, but also requires students to master the professional knowledge at the same time, need to know the cultural background of the language-specific, and then in working life skilled use of the language.

Students use English Good communication is an important objective of English teaching. Penetration in English teaching cross-cultural knowledge can not only improve the usefulness of the discipline of English, while students in a profound grasp of the basic cultural background knowledge of the language on to more profound understanding of some specialized knowledge, help students in communicating with people in the organization to better language, more to improve students' interpersonal skills.

Students' interest largely require some external excitation of English as a language, it makes a lot of vocabulary memory discouraged many students, learning English fear in the heart, we find that English is the poor performance of students first vocabulary and grammar learning and memory contradiction students, in order to improve the quality of teaching, which requires teachers in the teaching process, first find a way to improve students' interest in learning.

Cross-cultural knowledge to teach after all raise a good way to students' interest, if simply repeating textbook knowledge, learning, anyone would have tired of the day, so in addition to book knowledge, students can also see some extracurricular English publications, the initiative to understand the cultural background of English, teachers can also be targeted arrangement extracurricular tasks, so combined with the cultural knowledge of English to learn the language becomes very interested in, and will not particularly boring, but can also inspire students to a certain extent interest in learning.

Goal of education is to train for social needs comprehensive talent, English education is not only to equip students with professional knowledge of grammar, but also require students to have good English language comprehension skills, good English communication skills, the traditional but simple imparting book knowledge education can not meet the development goals, and therefore need to infiltrate English teaching cross-cultural research.

Students only mastered to a deeper understanding of the cultural background knowledge of language use this language, while the Western cultural backgrounds balance, a more profound understanding of the use of English grammar and improve their overall quality to meet the needs of the community, to achieve self value.

English teaching goal is to foster all-round development of the integrated talent, cross-cultural research in English teaching has greatly enhanced the quality of teaching. It not only enable students to master the basic knowledge of English, while students in understanding basic English cultural background knowledge, can turn a deeper understanding of English professional knowledge, and then guide their own learning.

\section{Conclusion}

With the progress of society and the reform of college English education, in order to adapt to the development objectives of education in English teaching teachers need to be applied to the cross-cultural study of the usual teaching, conducting professional knowledge to teach at the same time, the different Western cultural knowledge penetrate into the teaching of knowledge of English, the innovative teaching methods to improve students' interest, the balance in the West different cultural knowledge, students can more deeply understand some knowledge of grammar used in the basic understanding of cultural knowledge, while you can compare different cultures, learn from the 
best, to improve the quality of teaching at the same time develop the students' interest in learning.

\section{References}

[1] Zhang Yan. Practice Intercultural Education in English Teaching. China Education Innovation Herald (2008).

[2] Shen Xiangjing. Reflections on College English Teaching Intercultural Education. China Education Innovation Herald (2008).

[3] Bao Xiaofang. permeate intercultural awareness education in English teaching. Education Frontier (Comprehensive Edition), 2007.

[4] Ma Yong. Intercultural Education in English teaching content and methods. Teaching and Management. 2007.

[5] Lin Huiping. English in the teaching of cross-cultural awareness education. Fujian Education Institute .2006.

[6] Li Jianfu. Cultural Context Ways Localization English Teaching [J]. Foreign Language and Literature, 2006.

[7] Zhang Hongling. Intercultural education-oriented foreign language teaching: The history, present and future [J], Foreign Language World, 2012.

[8] Sun Xueke. Chinese intercultural education long way to go-Interview with Shanghai International Studies University, Cross-Cultural Research Center, deputy Director Zhang Hongling [J]. World Education information, 2015.

[9] Gao Xiangbin. American Multicultural Education [J]. Foreign Education, 2002. 